\title{
SOIL CHEMICAL ATTRIBUTES AND LEAF NUTRIENTS OF 'PACOVAN' BANANA UNDER TWO COVER CROPS ${ }^{1}$
}

\author{
JOSÉ EGÍDIO FLORI*2, GERALDO MILANEZ DE RESENDE ${ }^{2}$
}

\begin{abstract}
Banana is one of the most consumed fruits in the world, which is grown in most tropical countries. The objective of this work was to evaluate the main attributes of soil fertility in a banana crop under two cover crops and two root development locations. The work was conducted in Curaçá, BA, Brazil, between October 2011 and May 2013, using a randomized block design in split plot with five repetitions. Two cover crops were assessed in the plots, the cover 1 consisting of Pueraria phaseoloides, and the cover 2 consisting of a crop mix with Sorghum bicolor, Ricinus communis L., Canavalia ensiformis, Mucuna aterrima and Zea mays, and two soil sampling locations in the subplots, between plants in the banana rows (location 1) and between the banana rows (location 2). There were significant and independent effects for the cover crop and sampling location factors for the variables organic matter, $\mathrm{Ca}$ and $\mathrm{P}$, and significant effects for the interaction between cover crops and sampling locations for the variables potassium, magnesium and total exchangeable bases. The cover crop mix and the between-row location presented the highest organic matter content. Potassium was the nutrient with the highest negative variation from the initial content and its leaf content was below the reference value, however not reducing the crop yield. The banana crop associated with crop cover using the crop mix provided greater availability of nutrients in the soil compared to the coverage with tropical kudzu.
\end{abstract}

Keywords: Musa spp.. Organic farming. Macronutrients.

\section{ATRIBUTOS QUÍMICOS DO SOLO E DOS NUTRIENTES FOLIAR NA BANANEIRA 'PACOVAN' SOBRE DUAS COBERTURAS VEGETAIS}

RESUMO - A banana é uma das frutas mais consumidas no mundo, sendo explorada na maioria dos países tropicais. O objetivo deste trabalho foi avaliar os principais atributos da fertilidade do solo na bananeira sob duas coberturas do solo e dois locais de crescimento das raízes. O trabalho foi conduzido em Curaçá, BA, entre outubro de 2011 e maio de 2013, no delineamento experimental de blocos casualizados, no esquema de parcelas subdivididas, com cinco repetições. Nas parcelas foram avaliadas duas coberturas vegetais (cobertura 1 - Pueraria phaseoloides e cobertura 2 - coquetel vegetal com Sorghum bicolor, Ricinus communis L, Canavalia ensiformis, Mucuna aterrima e Zea mays e nas subparcelas: local 1- Amostragem de solo entre planta na linha da bananeira e local 2 - Amostragem de solo na entrelinha da bananeira. Verificou-se efeitos significativos e independentes para o fator cobertura vegetal e local de amostragem para as variáveis M.O., Ca e $\mathrm{P}$ e efeitos significativo da interação cobertura vegetal com os locais de amostragens do solo para as variáveis potássio, magnésio e soma de bases trocáveis. A cobertura vegetal com o coquetel e o local da entrelinha apresentaram o maior teor de matéria orgânica. O potássio foi o nutriente que teve a maior variação negativa em relação a caracterização inicial e seu teor foliar foi abaixo do valor de referência, mesmo assim não reduziu a produtividade da cultura. $\mathrm{O}$ cultivo de bananeira associado à cobertura do solo no arranjo com coquetel vegetal proporcionou maior disponibilização de nutrientes no solo, comparado a cobertura com kudzu tropical.

Palavras-chave: Musa spp.. Cultivo orgânico. Macronutrientes.

\footnotetext{
*Corresponding author

${ }^{1}$ Received for publication in 08/12/2014; accepted in 02/03/2016.

${ }^{2}$ Centro de Pesquisa Agropecuária do Trópico Semiárido, Petrolina, PE, Brazil; egidio.flori@embrapa.br; geraldo.milanez@embrapa.br.
} 


\section{INTRODUCTION}

Banana is one of the most consumed fruits in the world, which is grown in most tropical countries. The world banana production reached 102 million tons in 2012, and the estimated production in Brazil was 7.3 million tons in 2014 (IBGE, 2014). The International Federation of Organic Agriculture pointed to Brazil as the $10^{\text {th }}$ largest producer of organics, considering the planted area. (ORGANICNET, 2014).

The production and consumption of organic foods, including fruits, have been presenting an upward trend in most countries. The data showing the increase of the Brazilian organic market was released by the Development Promotion Institute (IPD, 2016) in 2011. The banana crop area is increasing in the main producing countries to meet this demand, such as in the Dominican Republic (18,621 ha), Ecuador (12 062 ha), Peru (5,681 ha) and Costa Rica $(4,605$ ha) (IFOAM, 2011). The major importers of banana produced in organic system are the United States, Canada and the European Union (SOTO, 2011).

Banana plants have large nutritional requirements, extracting greater amounts of potassium compared to nitrogen during the growing season, regardless of cultivar (SOARES et al., 2008). The extraction of soil nutrients from early stages up to the cluster formation is pronounced, with high absorption of potassium $(\mathrm{K})$, nitrogen $(\mathrm{N})$, calcium $(\mathrm{Ca})$, phosphorus $(\mathrm{P})$ and magnesium $(\mathrm{Mg})$ (SOARES et al., 2008). Hoffman et al. (2010), evaluating six banana cultivars with irrigation, found that potassium and nitrogen were most absorbed and exported macronutrients, followed by sulfur, calcium, magnesium and phosphorus.

The proper range of $\mathrm{K}$-foliar in irrigated banana from the cultivar 'Pacovan' is between 25 and $28 \mathrm{~g} \mathrm{~kg}^{-1}$ of leaf dry matter (BORGES; CALDAS, 2004). However, these plants can accumulate an amount of $\mathrm{K}$ exceeding their needs, which is commonly called superfluous intake of $\mathrm{K}$ (MEURER, 2006).

The limited use of chemical fertilizers in organic banana require a search for other alternatives for nutrient supply and soil fertility improvement, thus the green manure is a valuable resource for soil improvement (BORGES et al., 2010). Some plants have the ability to improve the fertility of the soil as legumes, grasses, and others (NASCIMENTO et al., 2003). The cultivation of these plants improve soil physical quality improving its structure by increasing macro and micropores (SANTOS et al., 2008).

The banana crop is favored by intercropping, especially regarding $\mathrm{N}$ and $\mathrm{C}$ contents, with legumes like Canavalia ensiformis (49-190 kg N ha-1 year $\left.^{-1}\right)$, Cajanus cajan (41-280 kg N ha ${ }^{-1}$ year $^{-1}$ ), Pueraria phaseoloides $\left(30-100 \mathrm{~kg} \mathrm{~N}^{-1}\right.$ year $\left.^{-1}\right)$, Crotalaria spectabilis (150-165 $\mathrm{kg} \mathrm{N}^{-1}$ year $^{-1}$ ) and Mucuna aterrima (170-210 $\mathrm{kg} \mathrm{N} \mathrm{ha}^{-1}$ year $^{-1}$ ) (BORGES et al., 2006). The tropical kudzu is recommended to intercropping with perennials crops because it develops under shading (OLIVEIRA; SOUTO, 2002). An advantage of a crop mix with legumes and non-legumes mixed at equal proportion is the producing of more dry matter in the soil (SILVA et al., 2013).

The release of $\mathrm{C}$ in intercropping with non-legumes species is faster than with legumes (GIONGO et al., 2011). The intercropping with various species protects the soil from weather agents, sequester $\mathrm{C}$ and fix atmospheric $\mathrm{N}$, thus presenting a potential to maintain or increase the organic matter content, mobilize and recycle nutrients and favoring the soil biological activity (PERIN, 2001; DUDA et al., 2003)

The positioning location of the nutrient supply in banana is important, since, according Sant'Ana et al. (2012), the plant root concentration and absorption decrease with the distance from the rhizome, and $60 \%$ of the roots are located from to 60 $\mathrm{cm}, 79 \mathrm{~cm}$ from the pseudostem.

Therefore, the objective of this work was to evaluate the soil fertility and leaf nutrient contents of banana, cultivar Pacovan, under two cover crops and two root development locations, grown in organic system.

\section{MATERIAL AND METHODS}

The experiment was conducted from October 2011 to May 2013, in the Irrigated Perimeter of Pedra Branca, Curaçá, BA, Brazil. The soil was classified as eutroferric red Argisol (EMBRAPA, 2013). Ten single samples from the $0-20 \mathrm{~cm}$ layer were collected for initial characterization of chemical attributes, resulting in a composite sample, following the methodology used by Donagema et al. (2011). The results showed the values of water $\mathrm{pH}$ (7.1), $\mathrm{P}$ (Mehlich-1, $\left.59 \mathrm{mg} \mathrm{dm}^{-3}\right)$, K $\left(0.32 \mathrm{cmol}_{\mathrm{c}} \mathrm{dm}^{-3}\right), \mathrm{Ca}$ $\left(3.1 \mathrm{cmol}_{\mathrm{c}} \mathrm{dm}^{-3}\right), \mathrm{Mg}\left(2.4 \mathrm{cmol}_{\mathrm{c}} \mathrm{dm}^{-3}\right), \mathrm{Na}(0.05$ $\left.\mathrm{cmol}_{\mathrm{c}} \mathrm{dm}^{-3}\right)$, phosphorus (P) (75 ppm), sum of bases (SB) $\left(5.87 \mathrm{cmol}_{\mathrm{c}} \mathrm{dm}^{-3}\right)$, cation exchange capacity (CEC) $\left(6.99 \mathrm{cmol}_{\mathrm{c}} \mathrm{dm}^{-3}\right)$ and organic matter (OM) (8.6 $\mathrm{g} \mathrm{kg}^{-1}$ (Tedesco et al., 1995). The evaluated variety (Pacovan) had 1 year of age and was spaced four meters between rows and two meters between plants in the rows. The crop area had been managed in an organic system for over three years.

The experimental design was in split plot with five repetitions, resulting in 20 subplots (two treatments in plots with two treatments in subplots with five replications, totaling 20 experimental units). Two cover crops were assessed in the plots, the cover 1 consisting of tropical kudzu (Pueraria phaseoloides) and the cover 2 consisting of a crop mix with tropical kudzu, sorghum (Sorghum bicolor), castor bean (Ricinus communis L.), jack 
bean (Canavalia ensiformis), velvet bean (Mucuna aterrima) and maize (Zea mays); and two soil sampling locations in the subplots (root development locations) with ten sampling points, between plants in the banana row (location 1) and between the banana rows (location 2).

The subplots consisted of 20 plants. Ten single soil subsamples were collected at a depth of 0 $20 \mathrm{~cm}$ in each subplot location and replication to form a composite sample, totaling 20 samples. The soil samples were collected from between the rows (two meters from the pseudostem), and in the row, between plants (one meter from the pseudostem). The evaluated variables regarding chemical properties of soil fertility were $\mathrm{K}, \mathrm{Ca}, \mathrm{Mg}, \mathrm{SB}$ and $\mathrm{P}$ (Mehlich-1) (DONAGEMA et al, 2011.), MO (TEDESCO et al., 1995.), and the foliar contents of $\mathrm{N}, \mathrm{P}, \mathrm{K}, \mathrm{Ca}, \mathrm{Mg}, \mathrm{SB}, \mathrm{Cu}, \mathrm{Fe}, \mathrm{Mn}, \mathrm{Zn}$ and $\mathrm{Na}$ (BATAGLIA et al., 1983).

The cover crops were sown (broadcast seeding) in the area and incorporated to the soil at the flowering period in two flowering cycles. The banana crop was fertilized in the plant rows with 5 liters of an organic compost produced in the area (chicken manure, bean crop residues, native wood ashes and cassava extract) every six months during the experimental evaluation period.

Additional fertilizing was performed weekly during the experimental period with a manure based liquid bio-fertilizer at $3 \mathrm{~L} \mathrm{plant}^{-1}$, which consisted of $80 \mathrm{~kg}$ of fresh poultry manure diluted in $1.000 \mathrm{~L}$ of water and fermented for 30 days. The average composition of the bio-fertilizer regarding the macronutrients $\mathrm{N}, \mathrm{P}, \mathrm{K}, \mathrm{Ca}, \mathrm{Mg}$ and $\mathrm{S}$ were 0.56 , $1.96,15.5,17.6,1.50$ and $2.34 \mathrm{~g} \mathrm{~kg}^{-1}$, respectively, according to the methods proposed by Bataglia et al. (1983).

Irrigation was performed by micro-sprinklers with flow of $50 \mathrm{~L} \mathrm{~h}^{-1}$ for each two plants. This water amount was calculated based in the water demand (ETo) and crop coefficient (kc) at 1.0 (Coelho et al., 2003). Soil samples were collected before planting (initial characterization) and after two production cycles. Samples of the $3^{\text {rd }}$ leaf were collected after the emission of the $2^{\text {nd }}$ cluster, following the method of Bataglia et al. (1983) and the leaf nutrient contents were evaluated according to the method of Martin-Prevel (1977).

Analysis of variance were performed using the statistical program SISVAR (FERREIRA, 2003) and the averages were compared through the $\mathrm{F}$ test $(\mathrm{p}<0.05)$.

\section{RESULTS AND DISCUSSION}

The cover crop and sampling location factors presented independent significant effects for the variables $\mathrm{MO}, \mathrm{Ca}$ and $\mathrm{P}$ (Table 1), and the cover crop and sampling location interaction presented significant effects for the variables potassium, magnesium and total exchangeable bases (Table 2).

Table 1. Soil fertility attribute contents depending on the cover crop and sampling location after the $2^{\text {nd }}$ banana crop cycle.

\begin{tabular}{lccc}
\hline Cover crop & $\mathrm{OM}$ & $\mathrm{P}$ & $\mathrm{Ca}^{2+}$ \\
& $\mathrm{g} \mathrm{kg}^{-1}$ & $\mathrm{mg} \mathrm{dm}^{-3}$ & $\mathrm{cmol}_{\mathrm{c}} \mathrm{dm}^{-3}$ \\
\hline Tropical Kudzu & $10,6 \mathrm{~B}$ & $109^{\mathrm{ns}}$ & $3,3^{\mathrm{ns}}$ \\
Crop Mix & $15,2 \mathrm{~A}$ & $116^{\mathrm{ns}}$ & $3,7^{\mathrm{ns}}$ \\
Mean & 12,89 & 113 & 12,36 \\
CV (\%) & 11,53 & 29,64 & $2,8 \mathrm{~B}$ \\
Location & & & $4,1 \mathrm{~A}$ \\
Plant Row & $10,4 \mathrm{~B}$ & $89 \mathrm{~B}$ & 3,45 \\
Between Row & $15,4 \mathrm{~A}$ & $137 \mathrm{~A}$ & 15,75 \\
Mean & 12,89 & 113 & 31,40 \\
CV (\%) & 21,76 & & \\
\hline
\end{tabular}

Means in the columns followed by different letters are significant by the $\mathrm{F}$ test at $5 \%$; ${ }^{\text {ns }}$ : not significant; OM: organic matter; P: phosphorus; Ca: calcium; CV: coefficient of variation. 
Table 2. Soil fertility attribute contents with significant interaction with the cover crop and sampling location after the $2^{\text {nd }}$ banana crop cycle.

\begin{tabular}{|c|c|c|c|c|}
\hline \multirow{2}{*}{ Cover crop } & \multirow{2}{*}{ Location } & $\mathrm{K}^{+}$ & $\mathrm{Mg}^{2+}$ & SB \\
\hline & & \multicolumn{3}{|c|}{---------------- $\mathrm{cmol}_{\mathrm{c}} \mathrm{dm}^{-3}$--------------- } \\
\hline \multirow{2}{*}{ Tropical Kudzu } & Plant Row & $0,09 \mathrm{~B}$ & $1,1 \mathrm{~B}$ & $3,9 \mathrm{~B}$ \\
\hline & Between Row & $0,29 \mathrm{~A}$ & $1,6 \mathrm{~A}$ & $6,4 \mathrm{~A}$ \\
\hline \multirow{2}{*}{ Crop Mix } & Plant Row & $0,14^{\mathrm{ns}}$ & $1,3^{\mathrm{ns}}$ & $4,4 \mathrm{~B}$ \\
\hline & Between Row & $0,17^{\mathrm{ns}}$ & $1,3^{\mathrm{ns}}$ & $6,0 \mathrm{~A}$ \\
\hline $\mathrm{CV}(\%)$ & & 26,88 & 11,08 & 5,76 \\
\hline
\end{tabular}

Means in the columns followed by different letters were significant by the $\mathrm{F}$ test at $5 \%$; ${ }^{\text {ns. }}$ not significant; $\mathrm{K}$ : potassium; $\mathrm{Mg}$ : magnesium; SB: sum of base.

The cover crop mix and the between-row location presented the highest contents of organic matter. The crop mix provided greater $\mathrm{C}$ content from non-leguminous species compared to the plots receiving only tropical kudzu. This result confirms those found by Giongo et al. (2011), who found greater availability of carbon and, consequently, OM in the soil with non-leguminous species (Table 1).

The $\mathrm{P}$ and $\mathrm{Ca}$ contents were higher in the between-row location, which may be explained by the crop lower nutrient absorption in this location (further from the rhizome), caused by the smaller root volume compared to the row location (Table 1). These result confirms those found by Sant'Ana et al. (2012), who reported that the lower plant root concentration and absorption is depending on the distance from the rhizome, and that $60 \%$ of the roots are located at $60 \mathrm{~cm}$ depth and $79 \mathrm{~cm}$ from the pseudostem.

The cover crop and sampling location presented significant interaction for the variables $\mathrm{K}$, $\mathrm{Mg}$ and SB (Table 2). The kudzu cover crop and the between-row location presented highest values of $\mathrm{K}$ $\left(0.29 \mathrm{cmol}_{\mathrm{c}} \mathrm{dm}^{-3}\right), \mathrm{Mg}\left(1.6 \mathrm{cmol}_{\mathrm{c}} \mathrm{dm}^{-3}\right)$ and SB (6.4 $\left.\mathrm{cmol}_{\mathrm{c}} \mathrm{dm}^{-3}\right)$, compared to the $\mathrm{K}\left(0.09 \mathrm{cmol}_{\mathrm{c}} \mathrm{dm}^{-3}\right)$, $\mathrm{Mg}\left(1.1 \mathrm{cmol}_{\mathrm{c}} \mathrm{dm}^{-3}\right)$ and SB $\left(3.9 \mathrm{cmol}_{\mathrm{c}} \mathrm{dm}^{-3}\right)$ values in the row location. The SB in the crop mix and in the between-row location was higher than in the row location, which may be attributed to the lower root volume with the distance from the rhizome, reducing the plant absorption in this area. Result that is supported by the work of Sant'Ana et al. (2012).

The $\mathrm{K}$ content in the between-row location was significantly higher under kudzu cover, with 0.2 $\mathrm{cmol}_{\mathrm{c}} \mathrm{dm}^{-3}$ more $\mathrm{K}$ than in the row location. However, the $\mathrm{K}$ content was not sufficient to meet the need of the banana, which require $\mathrm{K}$ values above $0.60 \mathrm{cmol}_{\mathrm{c}} \mathrm{dm}^{-3}$ for dispensing potassium fertilization (BORGES; SOUZA, 2009). The Mg content and the sum of bases were also higher in the between-row with kudzu coverage. The sum of bases in the between-row was greater in both covers (Table 2).

Potassium presented lower values $\left(0.23 \mathrm{cmol}_{\mathrm{c}}\right.$ $\mathrm{dm}^{-3}$ in the between-row and $0.11 \mathrm{cmol}_{\mathrm{c}} \mathrm{dm}^{-3}$ in the crop row) than those found at the beginning of the experiment $\left(0.30 \mathrm{cmol}_{\mathrm{c}} \mathrm{dm}^{-3}\right)$, especially in the crop row. A decrease in potassium content in the soil occurred even adding this element through fertilization with the compost with native wood ash and bio fertilizer with chicken manure. This result confirms the potassium requirement of banana (MALAVOLTA, et al., 1989), and indicates the need for further studies regarding this nutrient in organic farming.

The highest values of the soil fertility attributes were found in the cover crop mix and in the between-row location. This result may be explained by the lower nutrient absorption in this area and by the fact that this location had higher nutrient recycling from the crop mix plants. This result is supported by the works of Sant'Ana et al. (2012), Borges and Souza (2009) and Giongo et al. (2011)

There was no difference in foliar nutrient contents for the cover crops (Table 3). The nutrient contents in the $3^{\text {rd }}$ leaf presented potassium content values below the required for the cultivar (BORGES; CALDAS, 2004). However, the crop yield obtained in the $1^{\text {st }}$ and $2^{\text {nd }}$ cycles had an average of $24 \mathrm{tha}^{-1}$, which was higher than the yield reported by Ribeiro et al. (2012). The crop yield obtained was good despite the low contents of $\mathrm{K}$-foliar and $\mathrm{K}$ in the soil, which denotes the need for further studies to establish a more specific requirement of $\mathrm{K}$ content for producing banana in organic systems. 
Table 3. Means of nutrient contents in the $3^{\text {rd }}$ leaf of banana, cultivar Pacovan, evaluated at the emission of the $2^{\text {nd }}$ cluster of plants grown in organic system and the reference values of foliar contents (Borges and Caldas, 2004).

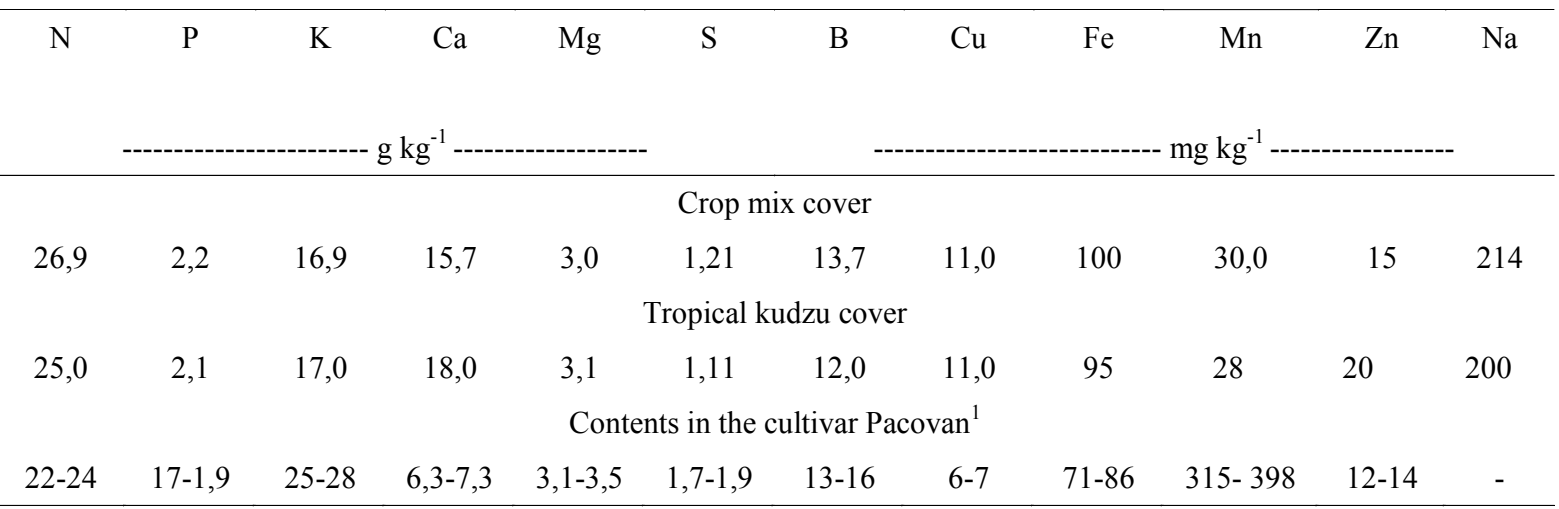

Borges and Caldas, 2004.

\section{CONCLUSIONS}

Potassium was the nutrient that had the highest negative variation from the initial characterization and its leaf content was below the reference value, however, it did not reduce the crop yield.

The banana crop associated with crop cover using the crop mix provided greater availability of nutrients in the soil compared to the coverage with tropical kudzu.

\section{REFERENCES}

BAtAgliA, O. C. et al. Métodos de análise química de planta. Campinas-SP: Instituto Agronômico, 1983. 48 p. (Boletim Técnico, 78).

BORGES, A. L. et al. Cultivo orgânico da bananeira. Cruz das Almas: Embrapa Mandioca e Fruticultura, 2006. 10 p. (Embrapa-CNPMF Circular Técnica, 81)

BORGES, A. L. et al. Sistema Orgânico de Produção para bananeira. Cruz das Almas: Embrapa Mandioca e Fruticultura, 2010. (EmbrapaCNPMF Orgânico em Foco, 1).

BORGES, A. L.; CALDAS, R. C. Teores de nutrientes nas folhas de bananeira, cv. Pacovan, sob irrigação Ciências e Agrotecnologia, Lavras, v. 28, n. 5, p. 1099-1106, 2004.

BORGES, A.L.; SOUZA, L.S. Calagem e adubação para bananeira. In: BORGES, A.L.; SOUZA, L.S. Recomendações de calagem e adubação para abacaxi, acerola, banana, laranja, tangerina, lima ácida, mamão, mandioca, manga e maracujá. Cruz das Almas: Embrapa Mandioca e Fruticultura Tropical, 2009. p. 57-73.

COELHO, E. F. et al. Irrigação da bananeira. Cruz das Almas: Embrapa Mandioca e Fruticultura, 2003. 8 p. (Embrapa-CNPMF Circular Técnica, 53).

DONAGEMA, G. K. et al. Manual de Métodos de Análise de Solo. 2. ed. Rio de Janeiro, RJ. 280 Embrapa Solos, 2011. 230 p.

DUDA, G. P. et al. Perennial herbaceous legumes as live soil mulches and their effects on $\mathrm{C}, \mathrm{N}$ and $\mathrm{P}$ of the microbial biomass. Scientia Agricola, Piracicaba, v. 60, n. 1, 139-147, 2003.

\section{FAO - FOOD AND AGRICULTURE} ORGANIZATION OF THE UNITED NATIONS. Production (2012). Disponível em <http:// faostat.fao.org/site/567/DesktopDefault.aspx?

PageID=567\#ancor $>$. Acesso em abril 2014 .

FERREIRA, D. F. Programa SISVAR: sistema de análise de variância: versão 4,6 (Build 6,0 ). Lavras: DEX/UFLA, 2003.

FERTILIDADE DO SOLO DO ESTADO DE MINAS GERAIS. Recomendações para o uso de corretivos e fertilizantes em Minas Gerais: $5^{\text {a }}$ aproximação. Viçosa; 1999. p.143-168.

GIONGO, V. et al. Decomposição e liberação de nutrientes de coquetéis vegetais para utilização no Semiárido brasileiro. Revista Ciência Agronômica, Fortaleza, v. 42, n. 3, p. 611-618, 2011.

HOFFMANN, A. P. et al. Acúmulo de matéria seca e de macronutrientes em cultivares de bananeira irrigada1. Revista Brasileira de Fruticultura, Jaboticabal, v. 32, n. 1, p. 268-275, 2010.

IBGE - Instituto Brasileiro de Geografia e Estatística. Sistema de Recuperação Automática SIDRA. (2014). Disponível em <http:// www.sidra.ibge.gov.br/bda/prevsaf/default.asp? $\mathrm{z}=\mathrm{t \& o}=26 \& \mathrm{i}=\mathrm{P}>$. Acesso em 12 de ago. 2014. 
IFOAM - The International Federation of Organic Agriculture Movements. The World of Organic Agriculture Statistics and Emerging Trends, 2011. FiBL-IFOAM Report. IFOAM, Bonn and FiBL, Frick. 288 p.

IPD - Instituto de Promoção do Desenvolvimento. MERCADO BRASILEIRO DE PRODUTOS ORGÂAICOS. (2011). Disponível em: http:// www.ipd.org.br/upload/tiny_mce/

Pesquisa_de_Mercado_Interno_de_Produtos_Organi c. Acesso em 19 de jan. 2016.

MALAVOLTA, E.; VITTI, G. C.; OLIVEIRA, S. A. de. Avaliação do estado nutricional das plantas: princípios e aplicações. Piracicaba: Associação Brasileira para Pesquisa da Potassa e do Fosfato. Piracicaba, SP, 1989. 201 p.

MARTIN-PRÉVEL, P. Echantillonnage du bananier pour l'analyse foliare: conséquences des différences de techniques. Fruits, Paris, v. 32, n. 3, p. 151-166, 1977.

MEURER, E. J. Potássio. In: FERNANDES, M. S. (Ed.). Nutrição mineral de plantas. Viçosa: Sociedade Brasileira de Ciência do Solo, 2006. cap. 11, p. 281-298.

NASCIMENTO, J. T. et al. Efeito de leguminosas nas características químicas e matéria orgânica de um solo degradado. Revista Brasileira de Engenharia Agrícola e Ambiental, Campina Grande, v. 7, n. 3, p. 457-462, 2003.

NEVES, R. L. L. et al. Extração de nutrientes em banana (Musa sp.) cv. Pacovan. Ciência Agronômica, Fortaleza, v. 22, n. 1/2, p. 115-120, 1991.

OLIVEIRA, F. L.; SUTO, S. M. Comportamento de leguminosas forrageiras tropicais sob sombreamento. Pesquisa Agropecuária Gaúcha, Porto Alegre, RS, v. 8, n. 1-2, p. 67.74, 2002.

ORGANICNET, 2014. Produtos orgânicos ganham a mesa do brasileiro. Disponível em: http:/www.organicsnet.com.br/2014/12/produtosorganicos-ganham-a-mesa-do-brasileiro/. Acesso em jan. 2016 .

PERIN, A. Desempenho de leguminosas herbáceas perenes com potencial de utilização para cobertura viva e seus efeitos sobre alguns atributos físicos do solo. 2001. 105p. Dissertação (Mestrado em Fitotecnia: Área de Concentração em Fertilidade do Solo) - Seropédica, Universidade Federal Rural do Rio de Janeiro. 2001.

RIBEIRO, L. R. et al. Avaliação de cultivares de bananeira em sistema de cultivo convencional e orgânico. Revista Brasileira de Fruticultura, Jaboticabal, v. 35, n. 2, p. 508-517, 2013.

SANT'ANA, J. A. V. et al. Distribuição de Raízes de Bananeira 'prata-anã' no Segundo Ciclo de Produção sob Três Sistemas de Irrigação. Revista Brasileira de Fruticultura, Jaboticabal, v. 34, n. 1, p. 124-133, 2012.

SANTOS, G. G. et al. Macrofauna edáfica associada a plantas de cobertura em plantio direto em um Latossolo Vermelho do Cerrado. Pesquisa Agropecuária Brasileira, Brasília, v. 43, n. 1, p. $115-122,2008$

SOARES, F. A. L. et al. Acúmulo, exportação e restituição de nutrientes pelas bananeiras "Prata Anã" e "Grand Nain. Ciência Rural, Santa Maria, v. 38, n. 7, p. 2054-2058, 2008.

SILVA, M. S. L. et al. Coquetel vegetal: produção de fitomassa e teores de macro e micronutrientes de espécies para adubação verde e/ou cobertura do solo. In: REUNIÃO NORDESTINA DE CIÊNCIA DO SOLO 1. 2013, Areias. Anais... CCA/UFPB, 2013.

SOTO, M. Situación y avances tecnologicos en la producción bananera mundial. Revista Brasileira de Fruticultura, Jaboticabal, v.33, p.013-028, 2011.

TEDESCO, M. J. et al. Análise de solo, plantas e outros materiais. 2 . ed. Porto Alegre, RS. Universidade Federal do Rio Grande do Sul, 1995. $174 \mathrm{p}$. 